Analytica Chimica Acta, 132 (1981) 187-193

Elsevier Scientific Publishing Company, Amsterdam - Printed in The Netherlands

\title{
PREPARATION AND ANALYTICAL PROPERTIES OF A CHELATING RESIN CONTAINING CYSTEINE GROUPS
}

\author{
CHUEN-YING LIU and PENG-JOUNG SUN* \\ Department of Chemistry, National Taiwan University, Taipei, Taiwan (Republic of China)
}

(Received 21st May 1981)

SUMMARY

A macroporous, cross-linked polyacrylonitrile copolymer was synthesized, the nitrile groups were converted to carboxylic acid by hydrolysis, and these carboxylic acid groups were treated with L-cysteine and 1,6-hexanediol (binding agent). Studies of the basic characteristics of this resin showed that it was highly selective for silver(I), mercury(II), gold(III) and platinum(IV) in aqueous acidic solution, the maximum capacities being $0.97,0.65,1.22$ and $0.39 \mathrm{mmol} \mathrm{g}^{-1}$ of dry resin, respectively. These four metal ions can be separated from each other, or concentrated from very dilute solutions, on a short column of the resin. The effects of different acids and of various common metal ions are reported.

The chemical behavior of an ion-exchange resin is determined by the nature of the functional groups attached to the hydrocarbon skeleton. Highly selective chelating resins can be synthesized by attaching appropriate ligand groups to the resin matrix. Cysteine, with three coordination sites, is an interesting ligand: at low $\mathrm{pH}$ values, only the sulfhydryl group is used in complex formation [1]. Studies have shown that sulfur-containing ligands exhibit better selectivity for the noble and heavy metals than their oxygen and nitrogen analogs [2]. Although many complexes of cysteine and its alkyl esters, both in solution and in the solid state with a variety of metals have been described [3-10], less information is available about the complexes of noble metals with cysteine $[11,12]$. No information on resins containing cysteine groups seems to have been reported. This paper describes the synthesis and basic characteristics of a resin with cysteine ligands and its analytical application in the chromatography of silver and some noble metals.

\section{EXPERIMENTAL}

\section{Instrumentation and reagents}

A Radiometer $\mathrm{pH}$ meter was used with saturated calomel (Type K401) and glass (Type G202B) electrodes, which were calibrated against Beckman standard buffer solutions of $\mathrm{pH} 4.00$ and 7.00. A Hitachi model 624 digital spectrophotometer connected to a Hitachi model $Q_{15}$ recorder and $10-\mathrm{mm}$ 
quartz cells was used for all absorbance measurements. Infrared spectra were recorded on a Perkin-Elmer model 580 spectrophotometer.

Analytical-grade chemicals were used throughout. Stock solutions of silver and platinum ions were standardized by classical titrimetric and gravimetric method. The stock solutions of all other metal ions were standardized by EDTA titration.

\section{Syrthesis of the chelating cysteine-containing resin}

A macroporous, cross-linked copolymer was prepared by the reaction of acrylonitrile and divinylbenzene as described by Vernon and Eccles [13]. The copolymer was air-dried, ground and sieved. The 60-100 mesh fraction was used for the further synthesis after being washed with $12 \mathrm{M} \mathrm{HCl}$, water and acetone. The copolymer (200 g) was stirred at $80^{\circ} \mathrm{C}$ with $1 \mathrm{l}$ of $37 \%$ $(w / v)$ sodium hydroxide solution until ammonia evolution ceased. The hydrolyzed polymer was cooled to room temperature, collected by filtration under suction and washed with $12 \mathrm{M} \mathrm{HCl}$, water and acetone.

For the first esterification, the carboxylic acid resin (200 g) was mixed with $600 \mathrm{~g}$ of molten 1,6-hexanediol (m.p. $41^{\circ} \mathrm{C}$ ) containing $50 \mathrm{ml}$ of $18 \mathrm{M}$ sulfuric acid as catalyst. The mixture was kept at $70^{\circ} \mathrm{C}$ for $30 \mathrm{~h}$ for esterification. The product was collected from the hot solution by filtration under sucticn, and washed with boiling methanol. For the second esterification, a mixture of $55 \mathrm{~g}$ of this product and $300 \mathrm{~g}$ of L-cysteine was added to $500 \mathrm{ml}$ of dioxane containing $20 \mathrm{ml}$ of $18 \mathrm{M}$ sulfuric acid. The mixture was heated at $90^{\circ} \mathrm{C}$ for $30 \mathrm{~h}$. The final product was collected by filtration under suction and washed sequentially with water, $12 \mathrm{M} \mathrm{HCl}$, water and acetone.

\section{Characterization of resin}

In order to verify the presence of cysteine groups in the synthesized resin, the infrared spectrum of the resin was obtained with $\mathrm{KBr}$ pellets after each step in the synthesis. The i.r. spectrum of the polyacrylonitrile-divinylbenzene copolymer showed bands at $2260-2240 \mathrm{~cm}^{-1}(-\mathrm{C} \equiv \mathrm{N})$, whereas the spectrum of the hydrolyzed product exhibited bands at 3500-2500, 1720, and $920 \mathrm{~cm}^{-1}(-\mathrm{COOH})$. The spectrum of the diol ester intermediate (Fig. 1a) exhibited bands at $3450(-\mathrm{OH}), 1735,1163$, and $1064 \mathrm{~cm}^{-1}$ (-COOR). The spectrum of the final product (Fig. 1b) showed bands at $2545(-\mathrm{SH})$, 2960,1610 , and $1513\left(-\mathrm{NH}_{3}{ }^{+}\right)$, and 1735,1163 and $1064 \mathrm{~cm}^{-1}$ (-COOR).

The nitrogen and sulfur contents, the hydrogen ion capacity, the capacities for $\mathrm{Ag}(\mathrm{I}), \mathrm{Hg}(\mathrm{II}), \mathrm{Au}(\mathrm{III})$ and $\mathrm{Pt}(\mathrm{IV})$ at $\mathrm{pH} \mathrm{1,} \mathrm{and} \mathrm{the} \mathrm{acid} \mathrm{ionization} \mathrm{con-}$ stants, were determined with the results shown in Table 1.

The distribution coefficients of the metal ions, defined by the equation $D=(\mathrm{mmol}$ of $\mathrm{metal} / \mathrm{g}$ of $\mathrm{dry} \mathrm{resin}) /(\mathrm{mmol}$ of metal $/ \mathrm{ml}$ of solution), were determined by using the batch equilibrium method. For each equilibrium experiment, $25 \mathrm{ml}$ of a mixture consisting of various amounts of acid and $0.3 \mathrm{mmol}$ of the metal ion in question was treated with $0.2 \mathrm{~g}$ of fresh resin and the solution was stirred for $8 \mathrm{~h}$ at room temperature $\left(25^{\circ} \mathrm{C}\right)$. The solution 


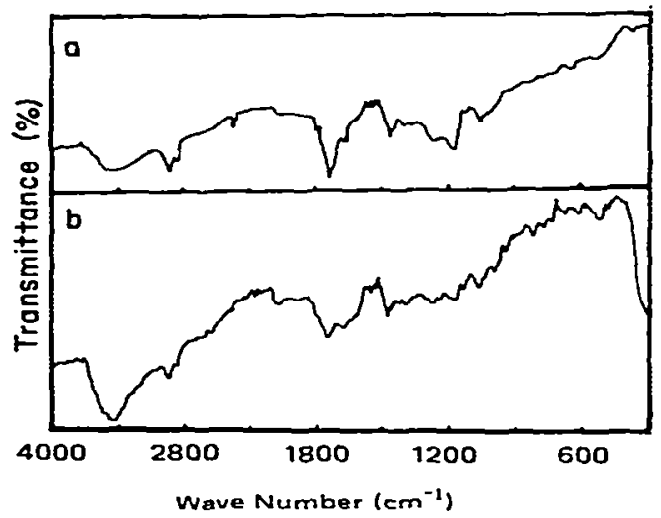

Fig. 1. Infrared spectra: (a) $\mathrm{RCOO}\left(\mathrm{CH}_{2}\right)_{6} \mathrm{OH}$ intermediate; (b) resin with cysteine group.

was filtered to remove the resin and the metal ion content of the filtrate was determined by conventional spectrophotometric procedures. The results are shown in Tables 2 and 3.

On the basis of these experiments, the order of selectivity of the resin was $\mathrm{Au}>\mathrm{Ag}>\mathrm{Hg}>\mathrm{Pt}>\mathrm{Mo}$. The results also show that the resin readily retains $\mathrm{Au}(\mathrm{III}), \mathrm{Ag}(\mathrm{I}), \mathrm{Hg}(\mathrm{II})$ and $\mathrm{Pt}(\mathrm{IV})$ from either $0.1 \mathrm{M} \mathrm{HClO}_{4}$ or $0.1 \mathrm{M}$ $\mathrm{HCl}$. Molybdenum is also retained by the resin from $0.1 \mathrm{M} \mathrm{HCl}$. Negligible adsorption was shown by the alkali metals, alkaline earths, iron(III), cobalt(II), nickel(II), zinc(II), cadmium(II), and lead(II) in $0.1 \mathrm{M}$ acid. This suggested that column chromatographic separation and concentration of metal ions (Pt(IV), $\mathrm{Hg}(\mathrm{II}), \mathrm{Ag}(\mathrm{I}), \mathrm{Au}(\mathrm{III})$ ) should be possible with this resin.

\section{Chromatographic application}

The resin column (6 $\mathrm{mm}$ i.d., $55 \mathrm{~mm}$ long) was conditioned with 30 $\mathrm{ml}$ of $0.1 \mathrm{M} \mathrm{HCl}$ at $0.5 \mathrm{ml} \mathrm{min}-1$. A sample that contained $0.4-1.5 \mu \mathrm{mol}$ each of $\mathrm{Ag}(\mathrm{I}), \mathrm{Hg}(\mathrm{II}), \mathrm{Au}(\mathrm{III})$ and $\mathrm{Pt}(\mathrm{IV})$ in $0.1 \mathrm{M}$ acid was added to the column and the liquid level was allowed to drop to the top of the resin bed. The wall of the reservoir was rinsed with $0.1 \mathrm{M}$ hydrochloric acid and then $10 \mathrm{ml}$ of $0.1 \mathrm{M}$ hydrochloric acid was used to elute any other metal ions from the column while the above metals were retained. The retained

TABLE 1

Physical and chemical characterization of the cysteine-containing resin (60-100 mesh)

\begin{tabular}{|c|c|c|c|}
\hline $\begin{array}{l}\text { Percent cross-linking } \\
\text { Nitrogen content }\end{array}$ & $\begin{array}{l}5.8 \% \\
1.16 \mathrm{mmol}\end{array}$ & Gold capacityb & $1.22 \mathrm{mmol} \mathrm{g}^{-1}$ \\
\hline Sulfur content & $1.15 \mathrm{mmol} \mathrm{g}^{-1}$ & Silver capacity ${ }^{b}$ & $0.97 \mathrm{mmol} \mathrm{g}^{-1}$ \\
\hline Hydrogen ion capacity & $2.85 \mathrm{mmol} \mathrm{g}^{-1}$ & Platinum capacity & $0.39 \mathrm{mmol} \mathrm{g}^{-1}$ \\
\hline $\mathrm{pK} K_{\mathbf{a}}\left(-\mathrm{COOH},-\mathrm{NH}_{3}{ }^{*},-\mathrm{SH}\right)$ & $5.65,6.59,7.16$ & Molybdenum capacity ${ }^{b}$ & $0.22 \mathrm{mmol}^{-1}$ \\
\hline
\end{tabular}

aThe nitrogen content of the original copolymer was $25.0 \%$ (17.9 $\left.\mathrm{mmol}^{-1}\right)$. All weights refer to dry resin. 'At pH 1.0. 
190

TABLE 2

Distribution coefficients in perchloric, hydrochloric or hydrobromic acid of varied molarity

Final acidity (M)

Ion $0.1 \quad 0.5$

Perchloric acid

Ag $\quad 95 \quad 102$

Au $\quad 1360 \quad 2430$

$\mathrm{Hg} \quad \mathbf{5} \underline{3} \quad \underline{43}$

1.0

2.0

3.0

5.0

6.0

$\mathbf{7 . 0} \quad \mathbf{8 . 0}$

Pt $\quad 39 \quad 46$

$\begin{array}{rr}104 & 104 \\ 13300 & 18000 \\ 40 & 38 \\ 55 & 75\end{array}$

117
24300
22
68

$\begin{array}{rrrr}96 & - & - & - \\ 28300 & 20600 & 2800 & 1150 \\ 21 & 21 & 17 & 13 \\ 50 & 34 & 34 & -\end{array}$

Hydrochloric acid

$\begin{array}{lrrrrrrrrr}\mathrm{Au} & 220 & 315 & 337 & 442 & 473 & 473 & 537 & - & - \\ \mathrm{Hg} & 58 & 22 & 20 & 16 & 0 & 0 & - & - & - \\ \mathrm{Pt} & 17 & 6 & 9 & 14 & 9 & 4 & - & - & - \\ \mathrm{Mo} & 16 & 28 & 1 & 3 & 27 & 12 & 16 & 26 & -\end{array}$

Hydrobromic acid

\begin{tabular}{llllllllll}
$\mathrm{Au}$ & 112 & 195 & 165 & 282 & 374 & 326 & 195 & - & - \\
\hline
\end{tabular}

$\mathrm{Pt}(\mathrm{IV}), \mathrm{Hg}(\mathrm{II})$, and $\mathrm{Ag}(\mathrm{I})$ were eluted sequentially with $0.5 \mathrm{M} \mathrm{HCl}$, and with a $6 \mathrm{M} \mathrm{HCl}-2 \mathrm{M} \mathrm{HClO}_{4}$ solution. The metals were determined spectrophotonetrically as their chloride complexes at 262,229 and $213 \mathrm{~nm}$, respectively. The gold(III) retained by the resin was eluted with $0.1 \%$ thiourea in $0.1 \mathrm{M}$ $\mathrm{HCl}$ and determined spectrophotometrically at $269 \mathrm{~nm}$ as the thiourea complex. A separation curve for the 4-component mixture is shown in Fig. 2.

The effects of other metal ions on the recoveries of $\mathrm{Pt}, \mathrm{Hg}, \mathrm{Ag}$ and $\mathrm{Au}$ are listed in Table 4. Samples containing gold and various other metal ions were separated on the column by elution with $6 \mathrm{M} \mathrm{HCl}$; good recoveries of gold were obtained in all cases (Table 5).

TABLE 3

Distribution coefficients in mixtures of hydrochloric acid and perchloric acid

\begin{tabular}{|c|c|c|c|c|c|c|c|}
\hline \multirow[t]{3}{*}{ Ion } & \multicolumn{7}{|c|}{ Final concentration $(M)$} \\
\hline & $\mathrm{HClO}_{4}$ & 1.5 & 2.0 & 2.5 & 3.0 & 3.5 & 4.0 \\
\hline & $\mathrm{HCl}$ & 7.0 & 6.0 & 5.0 & 4.0 & 3.0 & 2.0 \\
\hline $\mathbf{A u}$ & & 498 & 548 & 577 & 578 & 578 & 676 \\
\hline $\mathbf{H g}$ & & 10 & 0 & 12 & 12 & 12 & 12 \\
\hline Pt & & 25 & 26 & 25 & 25 & 19 & 19 \\
\hline
\end{tabular}




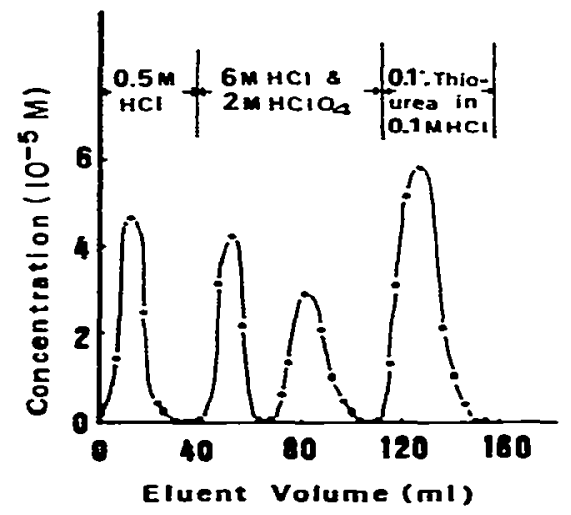

Fig. 2. Separation of $\mathrm{Pt}(\mathrm{IV}), \mathrm{Hg}(\mathrm{II}), \mathrm{Ag}(\mathrm{I})$ and $\mathrm{Au}(\mathrm{III})$ with the resin column. Column $55 \times 6 \mathrm{~mm}$ i.d.; flow rate $0.5 \mathrm{ml} \mathrm{min}^{-1} ; 0.45 \mu \mathrm{mol}$ each of $\mathrm{Ag}, \mathrm{Hg}$ and $\mathrm{Pt} ; 1.50 \mu \mathrm{mol}$ of Au.

\section{Concentration procedure}

The resin column (6 mm i.d., $25 \mathrm{~mm}$ long) was conditioned with $0.1 \mathrm{M}$ $\mathrm{HCl}$; then $500 \mathrm{ml}$ of a very dilute solution of the metal ion tested was passed through the column at a flow rate of $0.5 \mathrm{ml} \mathrm{min} \mathrm{m}^{-1}$. The sorbed metal ions were eluted and determined spectrophotometrically. The results are shown in Table 6.

\section{DISCUSSION}

The infrared frequencies for the cysteine-containing resin are in good agreement with those for the cysteine monomer [5]. A potentiometric titration curve obtained when the synthesized resin in the acid form was titrated with $0.1 \mathrm{M} \mathrm{KOH}$ at ionic strength 0.1 showed three breaks, only the first of which was quite distinct, corresponding to $\mathrm{pK}$ values of $5.65,6.59$ and 7.16 which are assignable to the residual carboxylic acid, amino and the sulfhydryl

TABLE 4

Effect of $5.0 \mu \mathrm{mol}$ of various metal ions on the recovery of $0.45 \mu \mathrm{mol}$ of $\mathrm{Pt}(\mathrm{IV}), \mathrm{Hg}$ (II) and $\mathrm{Ag}(\mathrm{I})$ and $1.50 \mu \mathrm{mol}$ of $\mathrm{Au}(\mathrm{III})$

\begin{tabular}{|c|c|c|c|c|}
\hline \multirow[t]{2}{*}{ Metal ion } & \multicolumn{4}{|c|}{ Recovery (\%) } \\
\hline & $\mathbf{P t}$ & $\mathrm{Hg}$ & $\mathrm{Ag}$ & $\mathrm{Au}$ \\
\hline $\mathbf{C u}$ & 97 & 100 & 100 & 100 \\
\hline $\mathbf{F e}$ & 99 & 101 & 101 & 100 \\
\hline $\mathbf{P b}$ & 97 & 99 & 99 & .100 \\
\hline $\mathrm{Zn}$ & 100 & 101 & 100 & 100 \\
\hline $\mathrm{Ni}_{\mathbf{i}}$ & 100 & 100 & 100 & 100 \\
\hline
\end{tabular}


TABLE 5

Separation of $1.50 \mu \mathrm{mol}$ of gold from $15 \mu \mathrm{mol}$ of another metal ion

\begin{tabular}{lcccccccccc}
\hline Metal ion & Ca(II) & Cd(II) & Co(II) & Cu(II) & Hg(II) & Mg(II) & Mn(II) & Ni(II) & Fe(III) & Pb(II) \\
\hline Au found $(\mu \mathrm{mol})$ & 1.48 & 1.40 & 1.45 & 1.47 & 1.40 & 1.51 & 1.46 & 1.45 & 1.58 & 1.64 \\
Error $(\mu \mathrm{mol})$ & $-\mathbf{0 . 0 2}$ & $-\mathbf{0 . 1 0}$ & -0.05 & -0.03 & -0.10 & +0.01 & -0.04 & -0.05 & +0.08 & +0.14 \\
\hline
\end{tabular}

group, respectively. Accordingly, the resin capacities were measured at $\mathrm{pH}$ 1.0, which was sufficiently acidic to avoid any interaction of the metal ions with other coordinated groups in the synthesized resin, and ensured that only the sulfhydryl group was involved in complexation.

The maximum capacity of the resin, determined by the batch method in perchloric acid medium, was $1.10 \mathrm{mmol} \mathrm{\textrm {g } ^ { - 1 }}$ for silver, $0.65 \mathrm{mmol} \mathrm{g^{-1 }}$ for mercury, $1.34 \mathrm{mmol} \mathrm{g}^{-1}$ for gold and $0.59 \mathrm{mmol} \mathrm{g}^{-1}$ for platinum (Fig. 3A). The sulfur content of this resin is $1.15 \mathrm{mmol} \mathrm{g}^{-1}$, so that $1: 1$ complexes are indicated for the resin functional group with silver and gold while 2:1 complexes are indicated for mercury and platinum. Several workers have similarly reported that cysteine binds silver and gold at a 1:1 ligand-to-metal ratio $[14,15]$, but mercury and platinum at a $2: 1$ ratio $[12,16]$. The formation of the 1:1 complex with gold suggests that gold(III) was reduced to gold(I) by the resin [15]. The higher than theoretical capacity for gold on the basis of 1:1 complex formation in perchloric acid medium may be due to some reduction of gold to the metal. In hydrochloric acid medium, the maximum capacity was $1.16 \mathrm{mmol} \mathrm{g}^{-1}$ for gold, $0.48 \mathrm{mmol} \mathrm{g}^{-1}$ for mercury and 0.14 mmol $\mathrm{g}^{-1}$ for platinum (Fig. 3B). The formation of a 1:1 complex of gold with the resin functional group is indicated. The reduction potential of the metal ions is clearly decreased by the formation of stable chloro complexes in the hydrochloric acid medium compared with in perchloric acid medium.

TABLE 6

Collection of metal ions from dilute solutions

\begin{tabular}{|c|c|c|c|}
\hline $\begin{array}{l}\text { Metal } \\
\text { ion }\end{array}$ & $\begin{array}{l}\text { Amount added }{ }^{a} \\
\text { ( } \mu \mathrm{mol})\end{array}$ & Eluent & $\begin{array}{l}\text { Recovery } \\
(\%)\end{array}$ \\
\hline \multirow[t]{2}{*}{$\mathrm{Ag}$} & 0.45 & $6 \mathrm{M} \mathrm{HCl}-2 \mathrm{M} \mathrm{HClO}_{4}$ & 100.2 \\
\hline & 0.23 & $6 \mathrm{M} \mathrm{HCl}_{-2} \mathrm{M} \mathrm{HClO}_{2}$ & 98.1 \\
\hline \multirow[t]{2}{*}{$\mathrm{Au}$} & $\begin{array}{l}1.50 \\
1.50\end{array}$ & $0.1 \%$ thiourea in $0.1 \mathrm{M} \mathrm{HCl}$ & 99.5 \\
\hline & 0.45 & $0.1 \%$ thiourea in $0.1 \mathrm{M} \mathrm{HCl}$ & 78.4 \\
\hline \multirow[t]{2}{*}{$\mathbf{H g}$} & 0.45 & $6 \mathrm{M} \mathrm{HCl}-2 \mathrm{M} \mathrm{HClO}_{4}$ & 101.2 \\
\hline & 0.23 & $6 \mathrm{M} \mathrm{HCl}^{-2} \mathrm{M} \mathrm{HClO}_{4}$ & 91.1 \\
\hline \multirow[t]{2}{*}{ Pt } & 0.45 & $0.5 \mathrm{M} \mathrm{HCl}$ & 99.6 \\
\hline & 0.23 & $0.5 \mathrm{M} \mathrm{HCl}$ & 65.7 \\
\hline
\end{tabular}

${ }^{\mathrm{a}}$ In $500 \mathrm{ml}$ of $0.1 \mathrm{M} \mathrm{HCl}$. 

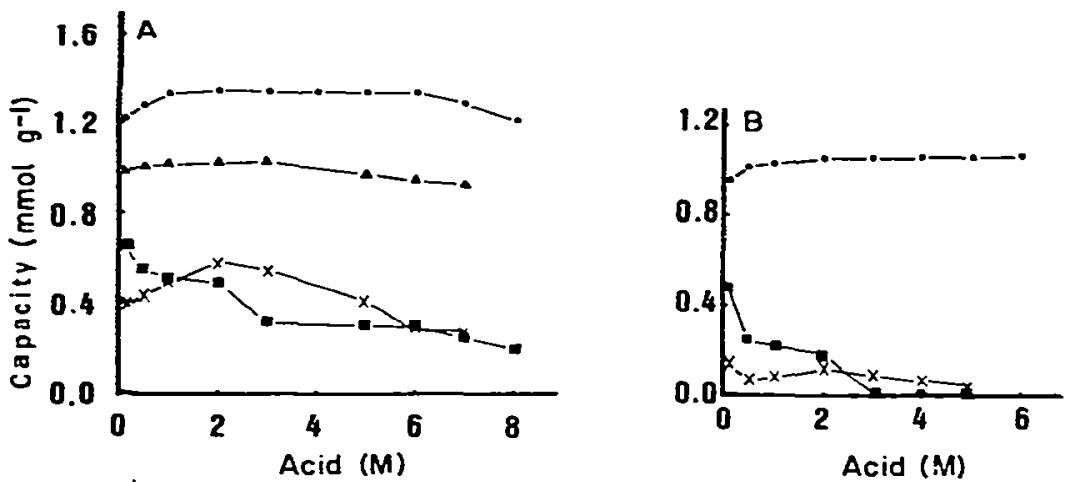

Fig. 3. Total capacity of the cysteine-containing resin for metal ions versus molarity of (A) perchloric acid and (B) hydrochloric acid: (•) $\mathrm{Au}(\mathrm{III}) ;(A) \mathrm{Ag}(\mathrm{I}) ;(=) \mathrm{Hg}(\mathrm{II})$; (x) Pt(IV).

The lower capacities for mercury and platinum in hydrochloric acid than in perchloric acid at the same hydrogen concentration can be ascribed to competition of the chloride ion with the resin ligand.

\section{REFERENCES}

1 P. Dhar and G. N. Mukherjee, J. Indian Chem. Soc., 56 (1979) 1258.

2 F. E. Beamish, Talanta, 14 (1967) 991.

3 C. A. McAuliffe and S. G. Murray, Inorg. Chim. Acta Rev.. 6 (1972) 103.

4 H. Shindo and T. L. Brown, J. Am. Chem. Soc., 87 (1965) 1904.

5 Y. K. Sze, A. R. Davis and G. A. Neville, Inorg. Chem., 14 (1975) 1969.

6 C. P. Sloan and J. H. Krueger, Inorg. Chem., 14 (1975) 1481.

7 P. de Meester, D. J. Hodgson, H. C. Freeman and C. J. Moore, Inorg. Chem., 16 (1977) 1494.

8 Y. N. Kothari and D. H. Busch, Inorg. Chem., 8 (1969) 2276.

9 A. Kay and P. C. H. Mitchell, J. Chem. Soc. (A), (1970) 2421.

10 V. R. Ott, D. S. Swieter and F. A. Schultz, Inorg. Chem., 16 (1977) 2539.

11 M. Chandrasenkharan, M. R. Udupa and G. Aravamudan, Inorg. Chim. Acta, 7 (1973) 88; J. Inorg. Nucl. Chem., 36 (1974) 1417.

12 G. Pneumatikakis and N. Hadjiliadis, J. Inorg. Nucl. Chem., 41 (1979) 429.

13 F. Vernon and H. Eccles, Anal. Chim. Acta, 82 (1976) 369.

14 G. D. Zegzhda, S. I. Neikovskii, T. V. Zegzhda, F. M. Tulyupa and N. A. Dorofeeva, Chem. Abstr., 90 (1979) 77249d.

15 T. D. Zucconi, G. E. Janauers, S. Donahe and C. Lewkowicz, J. Pharm. Sci., 68 (1979) 426.

16 W. Stricks and I. M. Kolthoff, J. Am. Chem. Soc., 75 (1953) 5673. 